\title{
THE CONSTITUTIONALITY OF THE NEW SEX WORK LAW
}

\author{
HAMISH STEWART ${ }^{*}$
}

In this article, the author considers the constitutionality of Canada's new law on prostitution: Bill C-36. When the new sex work law was first introduced into Parliament, a number of advocacy groups and commentators argued that it was unconstitutional because of its failure to respond to the concerns raised in Bedford v. Canada, a case where the Supreme Court of Canada struck down the old sex work law on the ground that its negative impact on sex workers' security of the person outweighed its nuisance abatement objective. This author agrees that Bill C-36 may be unconstitutional, but for a different reason. The new sex work law adheres to the constitutional norms invoked in Bedford by making use of two novel policy objectives: discouraging sex work and reducing the danger of sex work to sex workers. In practice, however, these objectives are likely to conflict with one another. As a result, Bill C-36 is an incoherent piece of legislation that may be unconstitutional for creating arbitrary and grossly disproportionate effects on the security of the person of sex workers.

\section{TABLE OF CONTENTS}

I. INTRODUCTION . . . . . . . . . . . . . . . . . . . . . . . . . . . . 69

II. The New Sex Work Law: Two Responses to BeDFORD . . . . . . . . 71

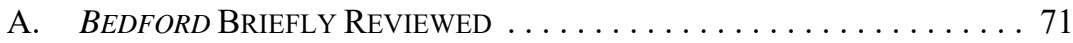

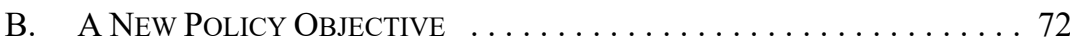

C. SPECIFIC RESPONSES TO BEDFORD . . . . . . . . . . . . . 76

III. The Constitutionality of the New Sex Work Law . . . . . . . . 80

A. The EFfect of The New Policy

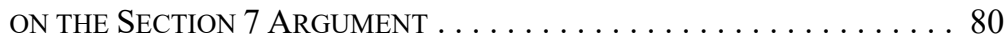

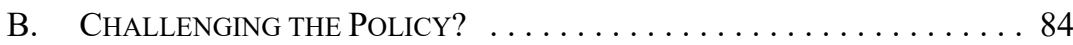

C. The Arbitrariness of InCONSISTEnt Policies $\ldots \ldots \ldots \ldots \ldots 86$

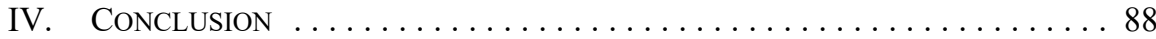

\section{INTRODUCTION}

In Canada (Attorney General) v. Bedford, ${ }^{1}$ the Supreme Court of Canada declared that three prostitution-related provisions of the Criminal Code were unconstitutional. ${ }^{2}$ The Court reasoned that the serious impact of two of these provisions on the security of the person of sex workers could not be justified by whatever beneficial effects they might have in promoting their nuisance abatement objectives. The third provision was found to be

* $\quad$ Faculty of Law, University of Toronto. I am very grateful to Kyle Kirkup and three anonymous reviewers for comments on a draft and to Manasvin Goswami, Thea Winterton-Perks, and Laura Petryshen for research assistance.

12013 SCC 72, [2013] 3 SCR 1101 [Bedford], rev'g in part Bedford v Canada (Attorney General), 2012 ONCA 186, 109 OR (3d) 1 [Bedford CA]. For commentary, see Hamish Stewart, "Bedford and the Structure of Section 7" (2014) 60:3 McGill LJ 575 [Stewart, "Structure of Section 7”]; Lisa Dufraimont, "Canada (Attorney General) v. Bedford and the Limits on Substantive Criminal Law under Section 7" (2014) 67 SCLR 483.

2 Sections 197 and 210 of the Criminal Code, RSC 1985, c C-46 contained the offence of keeping a common bawdy house. Section 212(1)(j) contained the offence of living off the avails of prostitution. Section 213(1)(c) contained the office of communicating in a public place. 
unconstitutionally overbroad. A central theme of the unanimous (9:0) decision was that sex work was lawful and that, absent a very significant legislative objective, it was not constitutionally permissible for Parliament to prohibit sex workers from taking elementary precautions to protect themselves from the dangers of this lawful work.

Parliament responded to Bedford by enacting Bill C-36. ${ }^{3}$ This new sex work law adopts a variant of what has been called "the Nordic model." "The centrepiece of the legislative scheme is the new offence of obtaining sexual services for consideration; but only the purchaser and not the seller of sexual services can be prosecuted for this offence. ${ }^{5}$ By enacting Bill C-36, Parliament has for the first time since the enactment of the first Criminal Code in 1892 criminalized the act of prostitution between adults. ${ }^{6}$ Moreover, Bill C-36 begins with a lengthy preamble stating, among other things, that "it is important to protect human dignity and the equality of all Canadians by discouraging prostitution, which has a disproportionate impact on women and children" and expressing Parliament's concern about the exploitation, objectification, and commodification of the human body and sexuality. ${ }^{7}$

When Bill C-36 was introduced into Parliament, and again when it came into force, a number of groups representing the interests of sex workers asserted that it was, in light of Bedford, obviously unconstitutional. ${ }^{8}$ Some commentators speculated that the Harper Government was showing its contempt for the Supreme Court of Canada by pushing through legislation that was certain to be invalidated. ${ }^{9}$ Others, more cautiously, suggested that the

Protection of Communities and Exploited Persons Act, SC 2014, c 25 [Bill C-36].

For a description of the Nordic model, see Sandra Ka Hon Chu \& Rebecca Glass, "Sex Work Law Reform in Canada: Considering Problems with the Nordic Model" (2013) 51:1 Alta L Rev 101. See also Sonia Lawrence, "Explaining the Appeal of Asymmetrical Criminalization: Jula Hughes (UNB), Vanessa MacDonnell (Ottawa) \& Karen Pearlston (UNB) on Options, Bedford, and the Role of Legal Professionals" (25 February 2014), Institute of Feminist Legal Studies at Osgoode (blog), online: $<$ ifls.osgoode.yorku.ca/explaining-the-appeal-of-asymmetrical-criminalization-jula-hughes-unb-vanessamacdonnell-ottawa-karen-pearlston-unb-on-options-bedford-and-the-role-of-legal-professionals/>. Criminal Code, supra note 2, ss 286.1(1), 286.5(2). For overviews of the new regime, see Hamish C Stewart, Sexual Offences in Canadian Law (Toronto: Canada Law Book, 2016) (loose-leaf updated 2016 release 21), ch 5:500.20 [Stewart, Sexual Offences]; Canada, Department of Justice, "Technical Paper: Bill C-36, Protection of Communities and Exploited Persons Act" (Ottawa: DOJ, 10 March 2015), online: <www.justice.gc.ca/eng/rp-pr/other-autre/protect/p1.html $>$ ["Technical Paper"].

The prostitution of a person under 18 years of age has been criminalized since 1989: see RSC 1985, c 19 (3rd Supp), s 9 as it appeared on 1 May 1989, creating the offence of obtaining "for consideration, the sexual services of a person who is under the age of eighteen years" as section 212(4) of the Criminal Code. The offence has been repealed because the conduct in question is subsumed by the new sex work law: see note 20 , below.

$7 \quad$ Bill C-36, supra note 3, Preamble.

Daniel Schwartz, "Sex Workers Like New Zealand Law, Not Canada's 'Nordic Model' for Prostitution," CBC News (5 June 2014), online: <www.cbc.ca/news/politics/sex-workers-like-new-zealand-law-notcanada-s-new-nordic-model-for-prostitution-1.2665431 > (reporting the views of the Canadian Alliance for Sex Work Law Reform); Senate, Proceedings of the Standing Senate Committee on Legal and Constitutional Affairs, 41st Parl, 2nd Sess, No 16 (17 September 2014) at 25-46 (Alan Young), online: $<$ www.parl.gc.ca/Content/SEN/Committee/412/lcjc/pdf/16issue.pdf > [Young, "Senate Testimony"]; Senate, Proceedings of the Standing Senate Committee on Legal and Constitutional Affairs," 41st Parl, 2nd Sess, No 16 (Brief of Pivot Legal Society and Downtown Eastside Sex Workers United Against Violence, online: <www.parl.gc.ca/Content/SEN/Committee/412/lcjc/Briefs/C-36/C-36_brief_PIVOT_ Legal\%20Society(Pacey-Porth)_E.pdf $>$ ).

$9 \quad$ See e.g. Andrew Coyne, "We Once Had to Wait Weeks for a New Harper Abuse of Power: Now We're Getting Them Two or Three Times a Day," The National Post (6 June 2014), online: <news.national post.com/full-comment/andrew-coyne-we-once-had-to-wait-weeks-for-a-new-harper-abuse-of-powernow-were-getting-them-two-or-three-a-day> (describing Bill C-36 as "not just in violation of the Constitution ... but in defiance of it"); Justin Ling, "Upsetting the Constitutional Balance," National Magazine (9 July 2014), online: <nationalmagazine.ca/Articles/July-2014-Web/Upsetting-theconstitutional-balance. aspx?> (the comments made by former Canadian Bar Association President Simon Potter). 
constitutionality of the legislation was doubtful because it was unlikely to do much to help sex workers and therefore did not truly respond to the defects identified in Bedford. ${ }^{10}$ Kathleen Wynne, Premier of Ontario, was among the doubters, and her government sought an opinion from the provincial Attorney General on that question. Yet, to the surprise of many, that opinion turned out to be that Bill C-36 was not clearly unconstitutional. ${ }^{11}$

They should not have been surprised. Although Bill C-36 may well be unconstitutional, its constitutional flaws are not immediately obvious. It responds to the constitutional defects of the former sex work law that were identified in Bedford, but in two rather different ways. The first concerns the purposes of the law. The main policy objective of Bill C-36 is to denounce and deter sex work itself, rather than to abate the nuisances that it creates; this shift of purpose is evident in both the preamble to the bill and in the structure of the new offences. It is highly unlikely that any court will say that denouncing and deterring sex work is a constitutionally impermissible objective. So, for section $7^{12}$ purposes, any detrimental effects of the law must now be measured against a different and perhaps weightier legislative purpose. Second, notwithstanding its generally punitive approach, Bill C-36 also has a purpose of improving sex workers' safety by decriminalizing some of the activities that were of specific concern to the Court in Bedford. If these two policy changes are considered separately and the law is then measured against the constitutional norms that were invoked in Bedford, Bill C-36 appears to be constitutionally valid. But the bill's two policy objectives are so at odds with each other that they are likely to create a constitutional problem. On the one hand, Bill C-36 criminalizes prostitution; on the other hand, it purports to ameliorate the legal situation of sex workers. In practice, these two objectives are likely to frustrate each other, and that frustration generates a plausible constitutional argument against Bill C-36: the incompatibility of its two purposes creates arbitrary and grossly disproportionate effects on sex workers' security of the person.

\section{THE NEW SEX WORK LAW: TWO RESPONSES TO BEDFORD}

\section{A. BEDFORD BRIEFLY REVIEWED}

Historically, sex work (prostitution) ${ }^{13}$ was not an offence in Canadian criminal law. But this lawful work was surrounded by numerous criminal prohibitions, notably the offences

10 See e.g. Angela Campbell, "Sex Work’s Governance: Stuff and Nuisance” (2015) 23:1 Fem Leg Stud 27. For an even more cautious response, see Michael Plaxton, "First Impressions of Bill C-36 in Light of Bedford" (2014), online: <papers.ssrn.com/sol3/papers.cfm?abstract_id=2447006>. See also Letter from Adam J Norget et al to the Right Honourable Stephen Harper (17 July 2014), online: $<$ https://bccla. org/wp-content/uploads/2014/07/LetterC36.pdf $>$. The open letter was signed by more than 220 legal experts.

11 See Allison Jones, “Ontario Review Finds Ottawa's Sex-Work Law Constitutional, Wynne Says,” The Globe and Mail (1 April 2015), online: <www.theglobeandmail.com/news/politics/ontario-reviewfinds-ottawas-sex-work-law-constitutional-wynne-says/article23734478/>. The substance of the opinion has not been made public.

12 Canadian Charter of Rights and Freedoms, s 7, Part I of the Constitution Act, 1982, being Schedule B to the Canada Act 1982 (UK), 1982, c 11 [Charter].

"Prostitution" was, under the Criminal Code, supra note 2 and in many other English-speaking legal systems, the legal term for the act of providing or obtaining sexual services for consideration. "Sex work" is the term preferred by many persons who engage in this work and by those who advocate for their safety and for the legalization of their work. Bill C-36, supra note 3 speaks of obtaining and providing "sexual services for consideration." I will use all of these terms, depending on the context. 
related to bawdy houses, living on the avails of the prostitution of another, and communicating in public for the purpose of engaging in prostitution (as either buyer or seller). Historically, notwithstanding the aura of moral disapproval that has always surrounded sex work and sex workers, courts repeatedly held that the purposes of these prohibitions were not to deter and denounce sex work as such, but to abate the nuisances associated with it and to protect sex workers from exploitation. ${ }^{14}$ The essence of the Bedford decision was that these purposes could not justify the dangers that the prohibitions imposed on sex workers. The bawdy house offence had a grossly disproportionate effect on security of the person; assuming that it fully achieved its nuisance abatement purposes, the prohibition on conducting a lawful business in a fixed location created severe dangers to sex workers. ${ }^{15}$ The offence of communicating for the purpose had a similar unconstitutional effect: by preventing sex workers on the street from taking elementary steps to screen potential clients, it created dangers to their security of the person that were grossly disproportionate to its nuisance abatement objectives. ${ }^{16}$ And the offence of living on the avails was unconstitutionally overbroad, in that it criminalized people who were in businesslike and other non-exploitative relationships with sex workers. ${ }^{17}$ Thus, all three offences violated section 7 of the Charter. ${ }^{18}$ None of the violations were justifiable under section $1 .{ }^{19}$

Bill C-36 responds to Bedford in two quite different ways. First, it changes the policy behind the criminal regulation of sex work from one of nuisance control to one of outright moral disapproval (see Part II.B, below). Second, it attempts to repair the specific constitutional flaws identified in Bedford by immunizing sex workers and selected others from criminal prosecution for certain offences (see Part II.C, below).

\section{B. A New Policy ObJective}

The central purpose of the new sex work law is fundamentally different from that of the regime considered in Bedford. The preamble to Bill C-36 declares that in enacting the new law, Parliament was concerned about "the exploitation that is inherent in prostitution ... [and] the social harm caused by the objectification of the human body and the commodification of sexual activity." 20 The preamble further asserts that it is "important to protect human dignity and the equality of all Canadians by discouraging prostitution ... to denounce and prohibit the purchase of sexual services because it creates a demand for prostitution ... [and] the procurement of persons for the purpose of prostitution and the development of economic interests in the exploitation of the prostitution of others as well as the commercialization and institutionalization of prostitution." Finally, the preamble expresses Parliament's intention "to encourage those who engage in prostitution to report incidents of violence and to leave prostitution." ${ }^{21}$ Thus, the preamble suggests that the purpose of the new sex work law is to protect human dignity by deterring and denouncing prostitution.

Bedford, supra note 1 at paras 130-32, 137-38, 146-47.

Ibid at paras 130-36.

Ibid at paras 146-59.

Ibid at paras 137-45.

Charter, supra note 12, s 7.

Bedford, supra note 1 at paras 161-62.

Bill C-36, supra note 3, Preamble.

Ibid. 
But a preamble, while helpful in understanding the purposes of a statute, is not itself part of the statute. ${ }^{22}$ So to fully understand the policy behind Bill C-36, it is also necessary to interpret its provisions. I will argue that the new offences relating to obtaining sexual services for consideration, properly interpreted in accordance with ordinary principles of criminal liability and in relation to the other new offences, are designed to implement the principal policy objective of Bill C-36 — deterring and denouncing prostitution — by criminalizing prostitution.

The centrepiece of the new sex work law is the new offence relating to obtaining sexual services for consideration:

286.1(1) Everyone who, in any place, obtains for consideration, or communicates with anyone for the purpose of obtaining for consideration, the sexual services of a person is guilty of [a hybrid offence]. ${ }^{23}$

This offence is subject to a minimum penalty of a fine in every case, regardless of the mode of proceeding, even for a first offence. The minimum fine for a first offence ranges from $\$ 2,000$ where the Crown proceeds by indictment and the offence is committed in a public place (or in certain places open to public view ${ }^{24}$ ) down to $\$ 500$ where the Crown proceeds summarily and the offence is committed in any other place. Because there is a minimum penalty, a discharge (absolute or conditional) is not an available sentence; but because the minimum penalty is not a term of imprisonment, a conditional sentence is possible. ${ }^{25}$ If the Crown proceeds by indictment, the accused is entitled to the full panoply of Criminal Code procedures, including the right to have or to waive a preliminary inquiry and the right to trial by jury. It is difficult to imagine why a Crown prosecutor would choose to proceed by indictment for this offence; but if the prosecutor did, it is equally difficult to imagine an accused choosing a jury trial, unless it is to keep open the possibility of jury nullification. Section 286.1(2) enacts an indictable offence essentially identical to section 286.1(1), with a minimum term of imprisonment of six months for a first offence, where the person whose sexual services are obtained or sought is under 18 years of age. ${ }^{26}$

Four other offences are connected to the section 286.1 offence. It is an offence under section 286.2 to receive a material benefit from the commission of the section 286.1 offence. As discussed further in Part II.C below, this is a slightly narrower version of the former offence of living on the avails of the prostitution of another person. It is an offence under section 286.3 to procure another person to offer or to provide sexual services for consideration; this offence is essentially the same as the former offence of procuring a person to be a prostitute. It is an offence under section 286.4 to "knowingly [advertise] an offer to

Reference re Anti-Inflation Act, [1976] 2 SCR 373 at 422.

Criminal Code, supra note 2.

Specifically, "any place open to public view, that is or is next to a park or the grounds of a school or religious institution or that is or is next to any other place where persons under the age of 18 can reasonably be expected to be present" (ibid).

See ibid, ss 730 (discharge), 742.1 (conditional sentence).

Section 212(4), which previously criminalized the same conduct, was repealed along with the rest of section 212: Bill C-36, supra note 3, s 13. Strangely, Parliament subsequently attempted to replace section 212(4) with a new provision setting out enhanced minimum penalties, see Canadian Victims Bill of Rights, SC 2015, c 13, s 2. This purported replacement for section 212(4) is presumably of no effect. 
provide sexual services for consideration." 27 There was no corresponding offence under the former regime. ${ }^{28}$ Finally, the communicating provisions of section 213 have been revised to relate to section 286.1 and to focus on sex workers rather than on clients (who are already covered by section 286.1$)^{29}$

The offence of obtaining or communicating is said to have been inspired by the "Nordic model," according to which the purchaser of sexual services commits an offence but the seller does not. ${ }^{30}$ But that is not what Bill C-36 says. It would have been easy enough to add a subsection to section 286.1 stating explicitly that a person who provides sexual services for consideration does not commit an offence, but Parliament chose not to do that. Instead, to assess the criminal liability of a sex worker, one has read on to section 286.5(2):

\footnotetext{
No person shall be prosecuted for aiding, abetting, conspiring or attempting to commit an offence under any of sections 286.1 to 286.4 or being an accessory after the fact or counselling a person to be a party to such an offence, if the offence relates to the offering or provision of their own sexual services. ${ }^{31}$
}

It is implicit in this provision that the seller of sexual services is indeed guilty of the offence of obtaining sexual services; otherwise, there would be no need to immunize him from prosecution. An application of the ordinary principles of party liability supports this conclusion. The seller of sexual services aids the buyer's commission of the offence and so is a party to it under section $21(1)(b)$ of the Criminal Code: the seller does something that helps the buyer to commit the offence, knowing that the buyer intends to commit the offence, and intending to help the buyer. ${ }^{32}$ Moreover, depending on the facts, the seller may abet the buyer by encouraging him to commit the offence and so be a party under section 21(1)(c), or may counsel the buyer to commit it and so be a party under section 22(1). The buyer and the seller would be guilty of conspiring to commit the section 286.1(1) offence if they entered into an agreement for the purchase and sale of sexual services, whether or not the agreement was carried out. Section 286.5(2) does not exclude any of these ways in which a sex worker could be a party to an offence committed by a client or conspire with a client. The section does not say that the seller is not a party to the buyer's offence or that the seller is deemed not to be a conspirator; it says merely that "[n]o person shall be prosecuted" on such theories of liability "if the offence relates to the offering or provision of their own sexual services."

Criminal Code, supra note 2.

In 1990, Toronto's NOW Magazine was charged on the theory that its acceptance of sex workers' ads amounted to "communicating" under an earlier version of section 213 of the Code. The Crown withdrew the charges a few weeks later. See Glenn Wheeler, "NOW Magazine Hit by Morality Squad," NOW Magazine 10:1 (6-12 September 1990) 19. This incident is also briefly described in NOW Magazine's 25th anniversary retrospective page for the year 1990, see NOW Magazine, "1990 25th Anniversary Retrospective" (9 November 2006), online: <https://nowtoronto.com/news/1990/>. If the new sex work law is actually enforced, NOW Magazine and comparable publications across Canada can expect to be prosecuted under section 286.4 .

The elements of these new offences and their relationship to the former offences are discussed in more detail in Stewart, Sexual Offences, supra note 5, ch 5:500.20.

For brief descriptions of the "Nordic model," see Chu \& Glass, supra note 4.

Criminal Code, supra note 2.

The elements of party liability by aiding are knowing that the principal offender intends to commit the offence and acting with intent to assist the principal offender: see, most recently, $R v$ Briscoe, $2010 \mathrm{SCC}$ 13, [2010] 1 SCR 411 at paras 13-18. See also Senate, Proceedings of the Standing Committee on Legal and Constitutional Affairs, 41st Parl, 2nd Sess, No 15 (9 September 2014) at 32-41 (testimony of Don Piragoff), online: <www.parl.gc.ca/content/SEN/Committee/412/lcjc/pdf/15issue.pdf>. 
Moreover, a sex worker can certainly be prosecuted on accessorial theories of liability in relation to someone else's sex work: someone who encourages a buyer to seek out a prostitute is a counsellor or abettor; someone who intentionally facilitates an exchange of sex for money is an aider. ${ }^{33}$ Thus, criminal liability remains a real possibility for sex workers who work together. If, for example, one sex worker were to refer a client to another sex worker, section 286.5(2) would not protect the first from prosecution as a party to the client's offence of obtaining sexual services from the second.

The wording of section 286.5(2) also raises some intriguing procedural issues. Suppose a person is prosecuted for the section 286.1 offence, but claims that the transaction in question related "to [her] own sexual services," so that she is immunized from prosecution under section $286.5(2) .{ }^{34}$ What is the appropriate procedural vehicle for raising this defence? The first step would be a motion for a stay of proceedings on the ground of abuse of process: it is clearly abusive to prosecute someone in a situation where the Criminal Code expressly states that they shall not be prosecuted. Yet the threshold for a successful abuse of process claim is high and the burden of proof is on the applicant (here, the sex worker). ${ }^{35}$ And if there was a bona fide factual dispute as to whether the transaction related to their own services, the prosecution would not be abusive because the purpose of a criminal trial is precisely to decide such factual disputes. So, the matter would go to trial. But what procedural rules would apply to the determination of that factual issue? Is "not being the person who provided the services" an essential element of these offences, so that the Crown would have to prove beyond a reasonable doubt that the accused was not the person who provided the sexual services? That seems unlikely, as section 286.5(2) does not speak to the elements of the offences, but to whether the person should be prosecuted for the offences. Or does section 286.5(2) operate as a statutory defence, arising in principle after the Crown has established the elements of the crime? If so, an accused would have to lead or point to some evidence capable of supporting the claim that they were the person whose sexual services were at issue; the Crown would then have to disprove that claim beyond a reasonable doubt. ${ }^{36}$ Instead of the question of the accused's role in the transaction being a factual issue for trial, it might be that the accused would have to renew an abuse of process motion on the basis of the evidence heard at trial and on the motion itself. Perhaps that would be the most appropriate procedure: the usual remedy for a person who is guilty but who should not have been prosecuted is not an acquittal but a finding of guilt followed by a stay of proceedings. ${ }^{37}$ But then, once again, the burden of proof would be on the accused to show, on a balance of probabilities, that they were the seller. So a sex worker might be convicted notwithstanding a reasonable doubt about whether they were the seller of the services in question.

A similar doctrinal issue arises in the prosecution of offences arising from drug transactions. A seller is guilty of trafficking but a purchaser is guilty at most of possession. What about someone who facilitates a drug transaction? Is he a party to the seller's act of trafficking or to the buyer's act of possession? For various approaches to this problem, see $R v$ Madigan (1969), [1970] 1 OR 80 (CA); $R$ $v$ Poitras (1973), [1974] SCR 649; R v Greyeyes, [1997] 2 SCR 825; R v Ahamad (2003), 181 CCC (3d) 56 (Ont Sup Ct J).

Criminal Code, supra note 2.

$R v O$ 'Connor, [1995] 4 SCR 411.

This is the familiar "air of reality" threshold applied to this defence. On the "air of reality," see most recently $R v$ Simpson, 2015 SCC 40, [2015] 2 SCR 827 at para 32. See also the discussion in Stewart, Sexual Offences, supra note 5, ch 3:600.40.

37 See $R v$ Mack, [1988] 2 SCR 903 (stay of proceedings as remedy for entrapment); Lévis (City) $v$ Tétreault; Lévis (City) v 2629-4470 Québec inc, 2006 SCC 12, [2006] 1 SCR 420 at para 25 (stay of proceedings as remedy for officially induced error). 
These questions about the procedural implications of section 286.5(2) may seem somewhat arcane. Their importance for this paper is not how they will ultimately be resolved, but the mere fact that they so easily arise under the new sex work law. That sex workers could so easily be caught up in prosecutions and that, notwithstanding the wording of section 286.5(2), it is not obvious how to extricate them, supports the claim that the policy behind Bill C-36 is indeed to criminalize sex work. Under Bill C-36 sex workers are deeply enmeshed in questions of criminal liability; not just others' but their own.

The principal purpose of Bill C-36 is to discourage prostitution; it pursues that policy not only by criminalizing the purchaser but also by taking pains to ensure that a person who provides sexual services for consideration is indeed guilty of a crime, albeit one for which they cannot be prosecuted. ${ }^{38}$

\section{SPECIFIC REPONSES TO BEDFORD}

In addition to shifting the objectives of the criminal law concerning sex work, Bill C-36 attempts to eliminate from the Criminal Code all three of the specific constitutional defects that were identified in Bedford. The bill repeals the bawdy house offence entirely, replaces the "living on the avails" offence with a slightly more narrowly drawn "material benefit" offence, and narrows the scope of the communicating offence for which sex workers can be prosecuted (while, as noted above, dramatically expanding it for purchasers of sexual services). These responses to Bedford sit uncomfortably with the generally punitive approach of Bill C-36, and so create space for claims of arbitrariness and gross disproportionality.

\section{MOdifying THE BAwdy House OFFEnCE}

As noted above, the Supreme Court of Canada held that the effects of the offence of keeping a common bawdy house for the purpose of prostitution on sex workers' security of the person were grossly disproportionate to its nuisance abatement purposes. Bill C-36 repeals the bawdy house offence in relation to prostitution ${ }^{39}$ and replaces it with no new offence. So it may seem that those who provide sexual services for consideration can no longer complain that the Criminal Code prevents them from improving their safety by working indoors. ${ }^{40}$ But, as explained in the next section, the new "material benefit" offence makes it nearly as difficult to conduct indoor sex work in a lawful manner as it was under the old regime.

Plaxton, supra note 10 at 5-6, concludes, with some hesitations, that sex work is lawful under Bill C-36; Benjamin Perrin characterizes prostitution under Bill C-36 as "quasi-illegal or asymmetrically illegal" in Macdonald-Laurier Institute, "How To Make Canada's New Prostitution Laws Work," Commentary (October 2014) 1 at 6, online: <www.macdonaldlaurier.ca/files/pdf/MLICommentaryPerrin1014Web Ready.pdf $>$.

39 It remains an offence to keep a common bawdy house for the practice of acts of indecency: see Criminal Code, supra note 2, s 210, as interpreted in $R v$ Labaye, 2005 SCC 80, [2005] 3 SCR 728 [Labaye]; Stewart, Sexual Offences, supra note 5, ch 5:500.10.30. Contrary to the suggestion made by Jacqueline M Davies in "The Criminalization of Sexual Commerce in Canada: Context and Concepts for Critical Analysis" (2015) 24:2 Can J Human Sexuality 78, it is highly unlikely that an act of prostitution meets the Labaye test for an "[act] of indecency" (Davies, ibid at 83). 


\section{From "Living ON THE AVAILS" TO "MATERIAL BENEFIT"}

In Bedford, the Court held that the purpose of the offence of living on the avails of prostitution of another was "to target pimps and the parasitic, exploitative conduct in which they engage." ${ }^{41}$ The offence was unconstitutionally overbroad in relation to this purpose because it failed to distinguish "between those who exploit prostitutes (for example, controlling and abusive pimps) and those who could increase the safety and security of prostitutes (for example, legitimate drivers, managers, or bodyguards). ${ }^{, 42}$ Bill C-36 repeals that offence and replaces it with the new offence of receiving a material benefit from the commission of the offence of obtaining sexual services for consideration. ${ }^{43}$ On its face, this offence is similar to the offence of living on the avails, but it is subject to four specific exceptions which narrow its scope. Section 286.2(4) states that the material benefit offences "do not apply" where the material benefit is received under any of the following four circumstances:

- " $[\mathrm{I}] \mathrm{n}$ the context of a legitimate living arrangement";

- " $[\mathrm{A}] \mathrm{s}$ a result of a legal or moral obligation of the person from whose sexual services the benefit is derived";

- "[I]n consideration for a service or good that they offer, on the same terms and conditions, to the general public"; or

- Where a good or service is not provided on the same terms and conditions as it is to the general public, but the person who provided the good or service "did not counsel or encourage that person to provide sexual services and the benefit is proportionate to the value of the service or good." 44

The statement that the material benefit offences "do not apply" is odd; Parliament might have said directly that notwithstanding sections $286.2(1)$ and (2), it is not an offence to receive a material benefit in these four situations. This choice of language is likely related to the roundabout treatment of a sex worker's criminal liability, as discussed in Part II.B, above. Rather than saying this conduct does not make the person a party to an offence, Parliament prefers to indicate that there will be no prosecutions in these situations.

It may be that the material benefit offence will be vulnerable to a vagueness challenge. It is far from clear, for example what is the scope of a "legitimate living arrangement" or a "moral obligation." It will be very difficult for sex workers and their family and friends, even those who sedulously attend to their potential criminal liability, to determine whether their living arrangements are "legitimate" or their transfer of funds is pursuant to a "moral 
obligation. ${ }^{45}$ But given the very low success rate of vagueness challenges, ${ }^{46}$ it is likely that courts will read these exemptions broadly and allow them to develop on a case-by-case basis.

There is a far more serious problem with the material benefit that is connected with the conflicting policy objectives of Bill C-36. Parliament has not tailored the material benefit offence with a view to permitting sex work to occur in a fixed, indoor location; quite the opposite. The exemptions granted in section 286.2(4) are themselves limited by section 286.2(5), which provides that section 286.2(4) does not apply in several situations. Some of these limits on the exemptions are unsurprising: they do not apply, for example, where the person receiving the benefit has "used, threatened to use or attempted to use violence, intimidation or coercion" 47 against a sex worker or has "provided a drug, alcohol or any other intoxicating substance ... for the purpose of aiding or abetting [a] person to offer or to provide sexual services for consideration." ${ }^{48}$ But section 286.2(5)(e) provides that the exemptions in section 286.2(4) are not available where the accused person "received the benefit in the context of a commercial enterprise that offers sexual services for consideration." 49 This limit makes the exemptions nearly meaningless in the context of sex work from a fixed, indoor location. Although there is no longer an offence of keeping a common bawdy house, owing to the section 286.2(5)(e) limit on the section 286.2(4) exemptions to the material benefit offence, it is very hard to set one up lawfully. ${ }^{50}$ It would seem that under the new sex work law, the only lawful way for a sex worker to maintain a permanent location in which to do this work is to buy a suitable building or apartment and operate the business entirely on their own. The sex worker would not be able to rent premises for this purpose because the landlord would then be committing the material benefit offence; although the landlord might appear to fall under the exemption in section 286.2(4)(c) for a service or good offered to the general public, they would lose that exemption under section $286.2(5)(e)$ because they would receive the rent "in the context of a commercial enterprise." 51 Similarly, the sex worker would not be able to lawfully hire a receptionist, bookkeeper, driver, or bouncer, as section 286.2(5)(e) would deny these employees any exemption from the material benefit offence.

The Department of Justice has suggested, under the heading "Bodyguards and Drivers," that Bill C-36 does not criminalize "individuals who offer protective services" to sex workers. $^{52}$ This reading is difficult to square with the plain wording of section $286.2(5)(e)$ or with the Department's own assertion that "Bill C-36 provides flexibility to the courts to find different types of enterprises, including informal ones, to be 'commercial' in nature,"53 thus triggering the limit on the exemptions to the material benefit offence: or, putting it more

See the overview in Hamish Stewart, Fundamental Justice: Section 7 of the Canadian Charter of Rights and Freedoms (Toronto: Irwin Law, 2012) at 127-33 [Stewart, Fundamental Justice].

Criminal Code, supra note 2, s 286.2(5)(a).

Ibid, s $286.2(5)(c)$.

Ibid, s 286.2(5)(e).

See also Plaxton, supra note 10 at 9

Criminal Code, supra note 2. I assume the material benefit offence is a full mens rea offence, so that the prosecution would have to prove that the accused knew or was wilfully blind to the facts constituting the offence. It would, no doubt, be easy to show in most commercial lease cases that the landlord was aware of the nature of the tenant's business.

52 Technical Paper, supra note 5, Part II.E. See also Perrin, supra note 38 (asserting that Bill C-36 "would allow legitimate security personnel to be legally hired by prostitutes" at 6). Perrin relies on section 286.2(4) but seemingly overlooks the limit in section 286.2(5)(e).

53 Technical Paper, ibid, Part II.B [emphasis added]. 
plainly, criminalizing everyone involved except the sex worker. If a sex worker's operation is characterized as "commercial," then section 286.2(5)(e) means that those who provide goods or services, without violence or exploitation, on the same terms and conditions as offered to the public at large, are guilty of receiving a material benefit from the work.

Thus, under the new sex work law, the only place where sex workers can conduct the (now unlawful) business of providing sexual services for consideration without causing others to commit the material benefit offence is in a residence or on business premises that they own themselves. They cannot lawfully hire any staff. And, because of the possibility of accessorial liability discussed in Part II.B above, it is doubtful that it is lawful for two or more sex workers to work together.

In Bedford, the Supreme Court of Canada found that the living on the avails offence was unconstitutionally overbroad because it captured relationships that were not parasitic or exploitative and because it prevented sex workers from protecting themselves by hiring "legitimate drivers, managers, or bodyguards." ${ }^{54}$ Bill C-36 removes criminal liability from those who are not parasites or exploiters of sex workers, but it is still overbroad in the other sense: drivers, managers, and bodyguards are liable for the material benefit offence. But that does not necessarily mean that the bill, or section 286.2(5) at least, is unconstitutional. The holding in Bedford was made in a context where sex work was lawful, whereas sections 286.2(4) and (5) are embedded in a regime where sex work is in general unlawful. It is not evidently unconstitutional to prohibit people from benefitting from an unlawful activity. The limiting effect of section 286.2(5)(e) is nevertheless relevant to the potential arbitrariness and gross disproportionality of Bill C-36; I return to this point in Part III.C, below.

\section{NARROWING THE SEX WORKER'S COMMUNICATING OFFENCE}

It is now an offence for anyone, anywhere, anytime, to communicate for the purpose of obtaining sexual services for consideration. ${ }^{55}$ But, as we have seen, a person "shall not be prosecuted" for this conduct in relation to their own sexual services — unless such communication occurs "in a public place or in any place open to public view, that is or is next to a school ground, playground or daycare centre. ${ }^{, 56}$ In that case, the person is guilty of a summary conviction offence. In respect of sex workers, this law is less restrictive than its predecessor $^{57}$ and its validity likely depends on the validity of the rest of the new sex work law. I will therefore not consider it separately. 


\section{The Constitutionality OF The NeW SeX Work LaW}

\section{A. The Effect of The NeW Policy ON THE SECTION 7 ARGUMENT}

I argued in Part II, above, that Bill C-36 effectively criminalizes sex work while at the same time attempting to respond to the specific constitutional defects of the old regime identified in Bedford. For the purposes of section 7 analysis, it is necessary to identify the legislative purpose of this change in the law. There are various ways of stating the purpose of the bill. The government that proposed this law to Parliament might have said, in accordance with the preamble, that the purpose of the law was to promote human dignity; critics of the law have characterized it as having a moralistic and ideological purpose ${ }^{58}$ For the purposes of overbreadth analysis under section 7, the purpose of a law must be stated in a way that is neither too general nor too specific; as the Supreme Court of Canada explained in Moriarity:

\footnotetext{
If the purpose [of the law] is articulated in too general terms, it will provide no meaningful check on the means employed to achieve it: almost any challenged provision will likely be rationally connected to a very broadly stated purpose.... On the other hand, if the identified purpose is articulated in too specific terms, then the distinction between ends and means may be lost and the statement of purpose will effectively foreclose any separate inquiry into the connection between them. ${ }^{59}$
}

Moreover, the articulation of the policy objective should be "precise and succinct." 60 This approach to stating a purpose is also suitable for applying the norms against arbitrariness and gross disproportionality because all three of these principles of fundamental justice are concerned with the effectiveness of a law in achieving its purposes in light of its impact on the interests protected by section 7 of the Charter; that is, with its instrumental rationality. ${ }^{61}$

I suggest that in light of its preamble and the interpretation of its provisions proposed above, the purposes of Bill C-36 are to discourage sex work while at the same time mitigating its dangers. The bill's instruments for pursuing this purpose are the criminalization of most aspects of sex work combined with limited exemptions for sex workers and certain other people from prosecution for the relevant offences. If I am wrong about that - if sex work is best characterized as remaining lawful under Bill C-36 - then it is very difficult to see how the new sex work law can be constitutionally valid because, as I argued in Part II.C above, it does not permit sex workers to conduct their work lawfully from an indoor fixed location and therefore suffers from the same flaws as the regime struck down in Bedford. ${ }^{62}$ But suppose I am right: suppose Bill C-36 is best understood as pursuing its purposes by criminalizing prostitution, subject only to limited exemptions from prosecution for sex workers. These new policy objectives have two important effects on the constitutional

Campbell, supra note 10 at 19; Young, "Senate Testimony," supra note 8 at 26-28.

$R v$ Moriarity, 2015 SCC 55, [2015] 3 SCR 485 at para 28.

Ibid at para 29.

Bedford, supra note 1 at para 107.

Cf Campbell, supra note 10 (organizing her critique of Bill C-36 around a sophisticated conception of "nuisance" that effectively subsumes the government's moral objections to sex work). Although Campbell's focus is not on the constitutionality of Bill C-36, by reading its underlying policy as nuisance-related, her approach supports the claim that a potential constitutional challenge would play out similarly to the one in Bedford, ibid. See also Young, "Senate Testimony," supra note 8. 
analysis in Bedford. ${ }^{63}$ First, the criminalization of sex work gives new life to the government's argument that the effects of the sex work law on a sex worker's section 7 interests are caused by their decision to engage in that work. Although I anticipate that the argument will be rejected again, the illegality of sex work has a second and more fundamental effect on the section 7 claim: the objective of the legislation will be weightier than it was under the old regime.

In Bedford, the applicants challenged the prohibition on keeping a common bawdy house on the ground that it had a grossly disproportionate effect on sex workers' security of the person: by preventing them from lawfully working in a fixed indoor location, the prohibition made outcalls and outdoor meetings with clients the only lawful forms of sex work. The social science evidence led at trial showed that this kind of work was much more dangerous than working indoors from a fixed location. But the government advanced a "choice" argument: whatever the dangers of sex work might be, they should not be attributed to the bawdy house law but to a sex worker's decision to choose that line of work. Thus, for section 7 purposes, it was not the law but personal choice that caused an impact on sex workers' security of the person. The Court rejected this "choice" argument, on two grounds: first, that some people have no real choice but to engage in sex work and, second, that sex work was in any event a lawful choice to make. Bill C-36 undermines the second ground. The Court's recognition that sex work was a lawful choice permeates the entire judgment, from the opening paragraph to the concluding comments about the variety of ways in which sex work might be regulated. ${ }^{64}$ The lawfulness of sex work was central to the Court's finding that the law affected security of the person: the law prevented them from taking elementary measures to protect themselves from the dangers of lawful sex work. This line of reasoning is no longer available in a hypothetical challenge to Bill C-36. Sex work is no longer lawful and the purpose of the new law is to discourage it, so it is now much more plausible for the government to argue that the best way to protect oneself from its dangers is not to take it up in the first place. Nevertheless, Bill C-36 does not affect the Court's first reason for rejecting the government's "choice" argument. A potential challenger can still argue that some people have no realistic choice but to make their living through sex work, and the fact that this is now an unlawful choice will not necessarily stop the section 7 claim in its tracks. ${ }^{65}$ There will, however, be significant pressure on a challenger to support this argument with social science evidence.

The second effect of the new policy is on the application of the three principles of fundamental justice that were successfully invoked in Bedford. All three of these principles involve a comparison between the effects of the law on the section 7 interests and the effects of the law in achieving its purposes. But, the great innovation in Bedford was to individualize the analysis of these principles, reserving questions of the larger social effects of a law for

63 Plaxton, supra note 10. See also Perrin, supra note 38 (also emphasizing the importance of Parliament's shift in purpose for the constitutional argument).

64 As Dufraimont, supra note 1 rightly says, "the lawfulness of prostitution [is] a dominant theme, perhaps the dominant theme, of the Supreme Court's judgment in Bedford" (ibid at 501). To give just one telling illustration of Dufraimont's point, the Court speaks of Parliament's "imposing limits on where and how prostitution may be conducted" (Bedford, supra note 1 at para 165). The possibility of outright criminalization does not seem to have occurred to the Court.

65 Cf Canada (Attorney General) v PHS Community Services Society, 2011 SCC 44, [2011] 3 SCR 134 at paras 97-106; Plaxton, supra note 10 at 6. 
consideration under section 1 of the Charter (if the analysis gets that far). ${ }^{66}$ For section 7 purposes, the Court is, apparently, prepared to assume that the law is or at least could be completely effective in achieving its purposes, but will then find a section 7 violation if the law has an unconstitutional effect on only one (possibly hypothetical) person. ${ }^{67}$ This approach may well make it easier for a Charter applicant to show a section 7 violation. On the other hand, if the government's objectives are sufficiently weighty and are assumed to be fully achieved, the Court may find that the principles of justice are satisfied; or, if not, the Court may entertain argument under section 1 as to whether the achievement of those weighty objectives will justify the violation of one (possibly hypothetical) person's section 7 right.

To see this point more concretely, consider the holding in Bedford concerning the bawdy house law. Having established that the prohibition on bawdy houses affected security of the person by making sex work more dangerous, the applicants then had to show that it violated a principle of fundamental justice. The Court held that it violated the norm against gross disproportionality. The application of this norm requires a comparison between the effects of the law in achieving its purposes and the effects of the law on the interests protected by section 7; in this case, security of the person. But the Court in Bedford insisted that this comparison required no empirical assessment of the effectiveness of the law in achieving its purposes; instead, the questions were "whether the law's purpose, taken at face value, is connected to its effects and whether the negative effect is grossly disproportionate to the law's purpose." ${ }^{\prime 68}$ It is difficult to know exactly what is meant by taking the law's purpose "at face value" when what is at issue is not the legitimacy of the purpose but the effectiveness of the law as a means for achieving that purpose. One possible interpretation of this idea is that the Court will assume that the law is completely effective in achieving its purposes; the Court will then ask whether, even in that extremely unlikely scenario, the impact of the law on the section 7 interest in question would be excessive. And that is how the Court analyzed the bawdy house law. Its purposes were to eliminate the nuisances associated with carrying on sex work in a fixed location. But if the law was completely effective - if every sex worker in Canada complied with it, thus eliminating any possibility of nuisances relating to bawdy houses - the impact on sex workers' security of the person would be so severe that it could not be justified by nuisance abatement.

It will be more difficult for this kind of argument to succeed against the new offences created by Bill C-36. The purpose of these new offences is to discourage sex work by criminalizing the purchase of sexual services and related conduct ${ }^{69}$ If taking this purpose at face value means assuming the law will be completely effective in achieving its purposes,

66 For a more detailed explanation of this point, see Stewart, "Structure of Section 7," supra note 1. This approach was affirmed in Carter v Canada (Attorney General), 2015 SCC 5, [2015] 1 SCR 331 at paras 71-90 [Carter].

67 Bedford, supra note 1("a grossly disproportionate, overbroad, or arbitrary effect on one person is sufficient to establish a breach of s. 7" at para 123).

$68 \quad$ Ibid at para 125 .

69 Or, as Campbell, supra note 10 puts it, "contemporary legal frameworks [including Bill C-36] continue to be driven by a moralistic ideology that refuses to contemplate sex work as having any legitimacy within public spaces" (ibid at 43). Indeed, Bill C-36 goes further than that: it denies the legitimacy of sex work in any space, public or private. The difficulty with integrating this kind of criticism into a constitutional challenge to Bill C-36 is that a court is very likely to say that it is constitutionally permissible for Parliament to make moral choices about sex work. Legalizing and legitimating sex work would, of course, also be a legislative choice based on moral values. 
we must assume that the law will eliminate the demand for sex work. No demand, no supply; no supply, no sex work; no sex work, no negative effects on sex workers' security of the person; and no violation of section 7 .

There are two possible strategies for avoiding this stark conclusion. First, one might argue that the effects of criminalization itself might be disproportionate to the objective. Assuming that discouraging and denouncing sex work is a legitimate legislative objective, it might be argued that criminalization is not a helpful means for achieving that objective. The thought would be that the consequences of prosecution and conviction for the individual accused person, one partner in a consensual transaction in which the other is not liable, are out of proportion to the benefits; Parliament's objectives, though important, could be pursued by other means. But the Court rejected this kind of argument in Malmo-Levine. ${ }^{70}$ The accused in that case challenged the constitutionality of the criminal prohibition on simple possession of marijuana. He argued, among other points, that the detrimental consequences of a conviction for simple possession were grossly disproportionate to Parliament's harmprevention objectives. But this is tantamount to saying that there are some objectives, otherwise within its legislative competence, that Parliament is constitutionally prohibited from pursuing by means of a criminal prohibition - an attractive proposition for those who believe in a restrained use of the criminal law, but not one likely to appeal to a court, which is likely to be reluctant to say anything that might be interpreted as supporting disobedience of the law as a strategy for undermining its constitutionality. As the Court put it in MalmoLevine, the consequences to an offender "are serious but they are part of the social and individual costs of having a criminal justice system"; ${ }^{71}$ moreover, they are "largely the product of deliberate disobedience to the law of the land." ${ }^{, 72}$

The second strategy is to interpret the Court's comment about taking the purpose of the law "at face value" as permitting an applicant either to accept that the law completely achieves its objective or to lead evidence concerning the effectiveness of the law. Then the applicant could argue, depending on the case, that either complete or partial achievement of the law's objectives is not worth the damage to the section 7 interests. In support of this interpretation, consider that the Court did not adopt its individualized approach to section 7 at random; it did so to ease the evidentiary burden on Charter applicants, and specifically to place the burden of adducing evidence about the social effects of legislation on the government, particularly in the context of section 1 justification. ${ }^{73}$ But that is not the same as saying that an applicant is forbidden from leading evidence about the effects of a law, if they want to do so. Moreover, a court would reach the point of considering the effectiveness of the law only after concluding that the law did after all have some impact on sex worker's liberty or security of the person. A court could not, for example, find on the one hand that the law increased the dangers of sex work and on the other hand that it completely achieved its objective of eliminating sex work. So it may be possible for an applicant to show with evidence that sex work is still very dangerous under the Criminal Code's new scheme. But even that showing will not translate immediately into a holding that the new scheme is grossly disproportionate, as any effect on sex workers' security of the person must now be

$R$ v Malmo-Levine; $R$ v Caine, 2003 SCC 74, [2003] 3 SCR 571 [Malmo-Levine].

Ibid at para 174 .

Ibid.

Bedford, supra note 1 at para 127. 
measured against the legislative objective of discouraging sex work, in a context where the work itself is no longer a lawful choice.

The new legislative objectives of Bill C-36 will also have important effects on the application of the other principles of fundamental justice deployed, though not applied, in Bedford. ${ }^{74}$ Consider, for example, a possible claim that it is arbitrary to criminalize sex work, while not criminalizing other behaviours that are also damaging to the government's stated objectives. There are many behaviours that the government legitimately discourages by means other than criminalization - behaviours such as "[s]moking, drinking, never thinking of tomorrow." ${ }^{, 75}$ We discourage this kind of conduct with strict regulation of the products in question (tobacco, alcohol, and pension plans), government propaganda, and tax incentives (for example, unfavourable tax treatment of tobacco and alcohol, in contrast with favourable tax treatment of retirement savings); we invoke penal law only as a last resort, to enforce the regulatory schemes. And so, the argument goes, it is arbitrary to use the criminal law rather than some other policy measures to control the harms associated with the conduct. But this kind of argument failed spectacularly in Malmo-Levine. The accused in that case argued that it was arbitrary to criminalize simple possession of marijuana while merely regulating arguably more harmful substances such as alcohol and tobacco. But, the Court said, that kind of differentiated policy choice is not the kind of arbitrariness that section 7 is concerned with: "[I]f Parliament is otherwise acting within its jurisdiction by enacting a prohibition on the use of marihuana, it does not lose that jurisdiction just because there are other substances whose health and safety effects could arguably justify similar legislative treatment."76 The kind of arbitrariness that section 7 is concerned about is the relation between the legislation and its objectives, not consistency of policy instruments across different objectives. It is not arbitrary in this sense to enact a law that criminalizes an activity when the very purpose of the law is to denounce and discourage that activity. The fact that Parliament might have chosen a different policy is not relevant to the question whether the policy actually chosen is arbitrary. The claim that Bill C-36 is arbitrary (or grossly disproportionate) will have to take a different form, as outlined in Part III.C, below.

\section{B. Challenging the Policy?}

In the previous section, I took the policy behind Bill C-36 at face value. It would be much more feasible to mount a constitutional challenge to the Bill C-36 regime if the policy itself could be questioned. If denouncing and deterring sex work is not a proper legislative purpose, then a court might attribute to the law a less exalted purpose, perhaps something similar to the nuisance abatement objectives of the old regime, and a section 7 challenge would have a much better chance of success. Or, if denouncing and discouraging sex work is not seen as an end in itself, but as a means to a more significant end, such as promoting equality and human dignity, then there might be room for a section 7 argument about the effectiveness of the means. Each of these strategies faces significant obstacles. But there is a third, related argument that may have some traction. That is not to question the objectives of Bill C-36 individually but to question their mutual consistency (see Part III.C, below).

The Supreme Court of Canada did not decide the applicants' arbitrariness claims in Bedford.

Duke Ellington, Irving Mills \& Mitchell Parish, "Sophisticated Lady" in The Great Music of Duke Ellington (Melville, NY: Belwin-Mills, 1973) 43 at 45.

Malmo-Levine, supra note 70 at para 139. 
The first strategy is to question the principal objective of Bill C-36 directly. Chu and Glass, for example, suggest that "an underlying aim to eradicate sex work is arguably impermissible" under the Charter. ${ }^{77}$ If that is right, then Bill C-36 is straightforwardly unconstitutional. But there are three significant obstacles to this claim. First, the courts are generally very reluctant to question Parliament's policy objectives, whether under section 7 for the purpose of applying the three principles of fundamental justice raised in Bedford or under section 1 for the purpose of applying the Oakes test. ${ }^{78}$ There appear to be no cases where a court has held that a law is arbitrary, overbroad, or grossly disproportionate because its objective is constitutionally impermissible; instead, courts accept the legislative purpose and consider the effects of the law on the interests protected by section 7. Chu and Glass invoke Labaye and Butler ${ }^{79}$ in support of their claim that a purely moralistic objective like the one implicit in the preamble to Bill C-36 would be constitutionally impermissible. But Labaye was a non-constitutional case involving ordinary statutory interpretation. ${ }^{80}$ And Butler was a section 1 case where the Court had already found a violation of a Charter right and, moreover, readily found that the law in question had a constitutionally acceptable objective (one that also figures among the objectives of Bill C-36): the promotion of women's equality. ${ }^{81}$ And, while the Court has recognized the possibility that a legislative objective might be per se unconstitutional for section 1 purposes, it is a rare case where the government's argument for justification has failed for this reason at the first stage of the Oakes test. ${ }^{82}$ Moreover, in section 1 cases, it is the objective of the Charter infringement, not the objective of the legislation as a whole, that is relevant. It is unlikely that a court would find that discouraging sex work was, in itself, an impermissible objective for the purpose of applying the section 7 principles of fundamental justice, before a specific Charter infringement had even been identified. There is no support in the case law for the proposition that a moral purpose of this kind is constitutionally improper: indeed, the Supreme Court of Canada has stated the opposite. ${ }^{83}$

Chu \& Glass, supra note 4 at 111. They were writing with reference to the "Nordic model," before Bill $\mathrm{C}-36$ was introduced into Parliament.

$R v$ Oakes, [1986] 1 SCR 103 [Oakes].

$R \vee$ Butler, [1992] 1 SCR 452 [Butler].

Labaye, supra note 39.

Butler, supra note 79 at 491-99. Bill C-36, supra note 3, Preamble. For an argument that the permissible objective was just a moralistic rehash of the impermissible objective, see Brenda Cossman, "Feminist Fashion or Morality in Drag? The Sexual Subtext of the Butler Decision," in Bad Attitude/s on Trial (Toronto: University of Toronto Press, 1997) 107. The best authority for Chu and Glass's claim is the Ontario Court of Appeal's comment that "a legislative purpose grounded in imposing certain standards of public and sexual morality is no longer a legitimate objective for purposes of Charter analysis" (Bedford CA, supra note 1 at para 189). The Court made this comment while characterizing the objectives of the bawdy house provision for the purposes of section 7 analysis. But the Court made this comment in support of its holding that the historical objectives of the bawdy house law were not very weighty. Moreover, unlike the Court of Appeal, the Supreme Court of Canada did not say that the government's asserted moral objectives would be illegitimate; rather, it found that they were not the objectives of the legislation.

82 The clearest example is $R$ v Big M Drug Mart Ltd, [1985] 1 SCR 295 at 351-53. See also Vriend v Alberta, [1998] 1 SCR 493 at 534-35, 540-41, where counsel for the Government of Alberta was unable to explain why the government had chosen to permit private discrimination on the ground of sexual orientation. The failure to articulate an objective led to the suspicion that the legislature's real purpose was simply to discriminate on the ground of sexual orientation, which would be per se unconstitutional. There are cases where the Court could not identify the purposes of the Charter infringement (see e.g. Sauvév Canada (Chief Electoral Officer), 2002 SCC 68, [2002] 3 SCR 519 at para 26) or has found that the objectives of the Charter infringement were not "pressing and substantial" (see e.g. Canada (Attorney General) v Hislop, 2007 SCC 10, [2007] 1 SCR 429 at para 52). But that is not to say that the purposes of these Charter infringements would have been per se unconstitutional if they could have been properly identified. And even in such cases, the Court normally proceeds with the rest of the proportionality test.

$83 \quad$ Butler, supra note 79 at 493; Malmo-Levine, supra note 70 at para 77. 
The second strategy is to treat the deterrence of sex work as a means to the end of promoting equality and human dignity, and then to argue that Bill C-36 is an ineffective means to that end. This strategy is unlikely to succeed as a challenge to the objectives of Bill C-36. The court will accept the end of promoting equality and dignity as constitutionally acceptable; and it will treat the argument that the bill is an ineffective means for promoting that end as a poorly-framed section 7 claim. As discussed in Part III.A, above, when applying the section 7 norms against arbitrariness, overbreadth, and gross disproportionality, the court prefers to articulate the end at a level of generality that is neither too specific nor too broad. Therefore, the court will likely treat "discouraging sex work" as an end, not as a means, and as suggested above, will consider the effectiveness of Bill C-36 as a means to that end.

\section{The Arbitrariness of Inconsistent Policies}

While challenging the moral objectives of Bill C-36 is unlikely to succeed, there is a related argument that may have some traction. That is not to question the objectives of Bill C-36 individually, but to question their mutual consistency. If Bill C-36 is internally contradictory, perhaps it is arbitrary or grossly disproportionate in section 7 terms, regardless of its effectiveness as a means for pursuing those objectives considered separately.

It is possible that Bill C-36 will succeed in its objective of discouraging sex work, that it will have no effect whatsoever, or that it will in practice aggravate the insecurity of sex workers by driving sex work outdoors. ${ }^{84}$ The last possibility is by far the most likely. There is little in the history of sex work to suggest that criminalizing it is an effective means of preventing it. The crucial findings of fact in Bedford were that street-level sex work is dangerous and that sex work from a fixed indoor location, with the assistance of staff, is the safest. As discussed in Part II.C, above, Bill C-36 does little or nothing to make indoor sex work lawful and, by expanding the criminalization of communicating by clients, makes outdoor sex work harder too. These effects would be inconsistent with the second purpose of Bill C-36. That would suggest, in turn, that Bill C-36 violated section 7. It would engage section 7 of the Charter by increasing the danger to sex workers; and that effect on security of the person would be arbitrary because the conflicting effects of the law would mean that it was not achieving its objectives - particularly its second objective of making sex work safer. $^{85}$

The Supreme Court of Canada has not always been entirely clear about the standard for arbitrariness, but the basic idea is that the law is essentially ineffective. In Carter, the Court said: "An arbitrary law is one that is not capable of fulfilling its objectives"; 86 in Bedford, the Court said that a law is arbitrary if its effect on the section 7 interests "bears no connection to its objective." ${ }^{, 87}$ One might think that a demonstration of arbitrariness in this sense would require some evidence as to how the law operates; if the evidence supported the finding that the law achieved its objectives to at least some degree, it would not be arbitrary. But Bedford

In support of the last possibility, see Campbell, supra note 10; Lawrence, supra note 4; Dufraimont, supra note 1 at 502; Young, "Senate Testimony," supra note 8.

C $f$ House of Commons, Proceedings of the Standing Committee on Justice and Human Rights, 41 st Parl, 2nd Sess, No 43 (10 July 2014) (testimony of Kyle Kirkup), online: <www.parl.gc.ca/House Publications/Publication.aspx?DocId $=6688136>$.

Carter, supra note 66 at para 83.

Bedford, supra note 1 at para 111 [emphasis in original]. 
indicates that the evidentiary requirement is minimal to say the least: the Court commented that to decide an arbitrariness claim, it was not necessary to "look to how well the law achieves its object," and indeed that an "arbitrary effect on one person is sufficient to establish a breach of [section] 7." ${ }^{98}$ It is very hard to understand exactly what this means. Arbitrariness is concerned with whether a law is connected with its objective and therefore with how well it achieves its objective. Moreover, it would certainly be possible for the law to achieve its objective to some extent, and yet not achieve it in its application to a particular individual: such a law would be overbroad, but would it be arbitrary because of its effect on one person or non-arbitrary because it achieves its objective to some extent?

Regardless of the answer to that question, the inconsistency between the two purposes of Bill C-36 also creates space for an argument of gross disproportionality similar to the one that succeeded in Bedford. Even if the new sex work law in effect criminalizes sex work, it is also intended to respond to the specific constitutional defects outlined in Bedford. But all of those defects were related to the trial judge's central finding of fact, that indoor sex work from a fixed location is the safest kind of sex work. The former bawdy house law had grossly disproportionate effects on sex workers' security of the person because it prevented them from working lawfully in such an environment; the former "living on the avails" offence was overbroad because (among other things) it prevented them from hiring staff. But, as I have argued above, the new "material benefit" offence has almost the same effect. It prevents a sex worker from lawfully conducting the work in a fixed, indoor location with staff unless the business can, somehow, be characterized as "non-commercial." For the purposes of a gross disproportionality claim, the deleterious effects of these limits on sex workers' security of the person may well outweigh the salutary effects of the law in achieving its anti-sex work objectives. While that is a question that ultimately will have to be addressed with evidence, including social science evidence, it seems very likely to be the basis for a powerful argument that the new sex work law is grossly disproportionate in section 7 terms.

It is unlikely that such an arbitrary or grossly disproportionate law could be justified under section 1; although the government might argue that this arbitrary effect was justified by the degree to which the principal objective of Bill C-36 was achieved, it is hard to imagine that a court which had taken the analysis this far would find that the moral benefits to be achieved by discouraging prostitution would justify the very concrete harms to sex workers. ${ }^{89}$ The inconsistency between the two purposes of Bill C-36 would not in itself indicate which one should yield, but in the context of a constitutional challenge of this kind, the Court would be looking for some way to help sex workers. A modest response would be to strike down section 286.2(5)(e), the provision that denies someone an exemption to the material benefit offence in the context of a commercial enterprise. If that provision were struck, sex workers would be able to rent space and hire employees such as receptionists, drivers, and bodyguards. But that would not eliminate the larger contradiction between the overall

Ibid at para 123 .

The Supreme Court of Canada has never upheld a violation of section 7 under section 1 of the Charter: Stewart, Fundamental Justice, supra note 45 at 289-305. I've argued elsewhere that the reasoning in Bedford opened up the possibility of section 1 justification of section 7 infringements: Stewart, "Structure of Section 7," supra note 1. The length of the section 1 analysis in Carter, supra note 57 at paras 94-123, suggests that this possibility is real, though in the result the Court found the limit on the section 7 right to be justified in neither Bedford nor Carter. See also R v Michaud, 2015 ONCA 585, 127 OR (3d) 81 (upholding an overbroad regulatory law under section 1). 
punitive purposes of Bill C-36 and its piecemeal responses to Bedford; for the threat of criminal liability to sex workers who work together, not to mention the threat of criminal liability to their clients, would remain. The most direct way to deal with the contradictions of Bill C-36 is to strike down the key offence of obtaining (or communicating for the purpose of obtaining) sexual services for consideration; the rest of the scheme would then fall away as the remaining offences depend on it.

\section{CONCLuSION}

Bill C-36 has two distinct policy objectives: discouraging sex work and reducing the danger of sex work to sex workers. Each objective is in itself constitutionally permissible. The constitutionality of the law therefore depends on the quality of the means chosen to pursue them. When the two objectives are considered separately, it is hard to see any constitutional defect in Bill C-36. Criminalizing sex work is a rational way of discouraging it; decriminalizing some aspects of sex work is a rational way of making it safer. But, considered together, the two objectives may well be irreconcilable. It seems very likely that vigorous prosecution of sex workers' clients and vigorous enforcement of the material benefit offence will make sex work more dangerous. Bill C-36 is an incoherent piece of legislation. This incoherence could well amount to the same kind of constitutional flaws that led the Supreme Court of Canada to strike down much of the former sex work law. 